\title{
IS E-LEARNING A SUITABLE TOOL FOR CORPORATE EDUCATION?
}

\author{
Marcela Sokolová ${ }^{1}$ \\ ${ }^{1}$ Univerzita Hradec Králové, Fakulta informatiky a managementu, Rokitanského 62, 50003 Hradec Králové 3 \\ Email:marcela.sokolova@uhk.cz.
}

\begin{abstract}
This article aims to discuss the main aspects that play a pivotal role in the issue of the introduction of e-learning in corporate training. The paper focuses on the economic issue of the introduction of e-learning in enterprise education system. The second main section is devoted to the efficiency of e-learning and presents the results of the experiment carried out, which compared the effectiveness of e-learning with traditional teaching in the acquisition of basic management skills. On the basis of the present analysis it is not possible to say that e-learning is always a good tool for the education of employees. But there are mentioned criteria and tools that can help you decide.
\end{abstract}

Keywords: corporate education, e-learning, a pedagogical experiment, traditional teaching.

JEL classification: I21, I22

Doručeno redakci: 2.4.2012; Recenzováno: 18.2.2013; 19.2.2013; Schváleno k publikování: 16.4.2013

\section{Introduction}

Currently, emphasis on education, development and workers' qualification continues to grow, because knowledge and skills are the basis for improving the quality of work performance of each employee, but also for the successful operation and prosperity of the whole organization. To ensure competitive advantage within the daily struggle of firms to obtain and maintain a good market position, it is necessary to have skilled and educated workers.

Armstrong (2007) says that the company's education core goals are primarily to increase the performance of regular workers and development of the skill to be able to perform new work with newly recruited workers as soon as possible and at minimal cost. Corporate education is seen as an investment in people, which should return to the company.

Unfortunately at the moment when an organization faces problems, especially financial problems, due to any reason, education is among the first areas where cuts will be made and the educational process is disrupted or in extreme cases completely suspended. Therefore, an organization must use all available methods of education, choose those that are not only effective but also financially acceptable so this situation does not have to occur.

The world is constantly evolving and changing, more new technology is coming on the market, including the field of education. One possibility is the introduction of e-learning in corporate training. Kopecky (2006) defines e-learning in a broader sense as the application of new multimedia technologies and Internet in education to improve its quality by enhancing the access to resources, services, information exchange and co-operation, in the narrower sense e-learning is seen especially as education, which is supported by modern technologies and is implemented through computer networks - especially Internet and intranet. According to Bartak (2008) e-learning is indicated as education with a direct or indirect use of electronic means and media, especially Internet. 
E-learning can not replace all forms of learning, but can significantly streamline the education system. The original reason for organizations to implement e-learning was mainly to reduce cost, but today it is obvious that e-learning has also many other benefits.

Many facts speak for implementation of e-learning, such as: (Poulova, 2010):

- time independence and individual study,

- $\quad$ possible reduction of costs compared to traditional education,

- $\quad$ in the case of quality-made courses, ensuring a high level of transmitted knowledge,

- $\quad$ standardized knowledge (everyone receives the same information),

- $\quad$ assessment of students under the same rules,

- $\quad$ to teach a large number of people in a short time,

- $\quad$ courses can be created in an interesting and entertaining way that will appeal to more students, etc.

On the other hand, it is obviously necessary to mention the possible negatives and barriers in the introduction of this form of study, such as: (Poulova, 2010):

- not suitable for everyone (computer literacy is needed),

- $\quad$ learning is not with a person

- $\quad$ problems with the motivation of participants,

- $\quad$ knowledge is given in one way, which may be unsuitable for some people,

- $\quad$ it is necessary to have the appropriate technical equipment (ICT technology) and others.

The decision-making process regarding the implementation of e-learning into the corporate education system is a very complex procedure that can be decomposed into several decision problems, but these themselves are very important, when in fact a breach of one of these conditions may result in a negative opinion towards the introduction of e-learning.

Before the incorporation of e-learning in the process of education, it is necessary to consider those aspects in particular (Šimonová, 2009):

- $\quad$ economic point of view;

- content of the course - the appropriateness of education of given issue through e-learning (efficiency);

- $\quad$ assumptions of educational institutions - ICT facilities, staffing;

- $\quad$ assumptions of students - ICT literacy, access to ICT.

The article further in detail focuses on the economic issue of the introduction of e-learning in enterprise education system. The second main section is devoted to the efficiency of elearning and presents the results of the experiment carried out, which compared the effectiveness of e-learning with traditional teaching in the acquisition of basic management skills.

\section{Economic aspects of the introduction of e-learning}

\subsection{Costs associated with the introduction of e-learning}

The introduction of e-learning is very often associated with high investment, which is true to some extent, because the initial costs are very high. But if the creation of an optimal education system is managed, which will work for a long time and enough students will be involved in it, then the given investments in the educational system of an organization will return. 
It is necessary to look at the costs, whether incurred or saved, from two perspectives:

- from the perspective of educational institution,

- $\quad$ from the perspective of learners (students).

\subsubsection{The perspective of educational institution}

Under the concept of educational institution, in our point of view we can include any entity whose primary or secondary mission is education. In our case it is an organization that wants to implement e-learning in education.

The cost of deploying e-learning can be divided into two groups:

1) Investment (initial) costs

a. $\quad$ Connecting to the Internet

b. Hardware and system software

c. Databases

d. LMS (Learning Management System)

e. Means for creation of the course

f. Methodological know-how, standards

g. Purchase of online courses

These costs incurred in the first phase of introduction of e-learning and in most cases they do not appear in the later phases. Their amount is largely derived from the level of the organization's ICT facilities. In the case that the facilities are at a good level, then the initial costs are decreased by the value of this equipment.

Very often these costs are quite high and many projects end for this reason.

\section{2) Operating (continuous) costs}

a. Development and production of online courses

b. Operation and administration of the LMS

c. The work of authors and lecturers of courses

We encounter these costs during the course of operation of e-learning, the amount is influenced by many factors such as the operational demands of the LMS, the level of obsolescence of the created courses and the need to create new ones, demands on the work of lecturers, etc.

\subsubsection{The perspective of the students}

From the perspective of learners, the cost of e-learning is much more explicit. The only cost factor is the question of access to ICT, and hence ICT literacy. The survey of the Czech Statistical Office (2012) shows, that d personal computer is currently owed by $64.8 \%$ of households and an active internet connection in the Czech Republic is used by more than 6 out of 10 households (61.7\%)."Moreover, some employees have access to computers and Internet at work. Of course, since the improved availability of modern technology, computer literacy has also been proportionally better. From this perspective, considerable savings can be seen, both financial (e.g. travel costs) and time (a student can determine themselves when they study).

\subsection{Comparison of e-learning cost versus traditional teaching cost}

In the previous text, the focus was put on the costs associated with e-learning. However, if we have to decide whether to introduce e-learning, it is necessary to compare it with an alternative, then it can have a meaningful ability, because in the decision-making process it is 
necessary to have at least two variants. If we spurn the variant not to learn at all, then the alternative is traditional teaching. One or the first important variable is the initial (investment) costs. This item is often very high and in many projects and decisions it can be only found in the variant of e-learning.

Considering the other, which are operating costs, and then we can see clear benefits in the elearning option. Table 1 compares the cost of e-learning and traditional teaching. Direct costs are those costs that are directly relevant to the educational process. Indirect costs are those that are incidental to some extent, but can be significantly high and important for decisionmaking. These indirect costs may be in certain cases carried by educational institutions, and sometimes by the students themselves.

Table 1: Cost comparison - e-learning vs. traditional teaching

\begin{tabular}{|c|c|c|c|}
\hline \multicolumn{2}{|c|}{ EXPENSES } & \multirow{2}{*}{$\begin{array}{c}\text { E-LEARNING } \\
\text { YES }\end{array}$} & \multirow{2}{*}{$\begin{array}{c}\text { TRADITIONAL } \\
\text { INSTRUCTION } \\
\text { YES }\end{array}$} \\
\hline DIRECT EXPENSES & $\begin{array}{l}\text { CREATING THE } \\
\text { COURSE }\end{array}$ & & \\
\hline & TUTORING & SOMETIMES YES & YES \\
\hline \multirow{6}{*}{ INDIRECT EXPENSES } & $\begin{array}{c}\text { PURCHASING THE } \\
\text { COURSE }\end{array}$ & YES & YES \\
\hline & $\begin{array}{c}\text { RENT FOR } \\
\text { CLASSROOMS }\end{array}$ & $\begin{array}{c}\text { SOMETIMES YES } \\
\text { (RARELY) }\end{array}$ & YES \\
\hline & $\begin{array}{l}\text { CLASSROOM } \\
\text { EQUIPMENT }\end{array}$ & $\begin{array}{c}\text { SOMETIMES YES } \\
\text { (RARELY) }\end{array}$ & YES \\
\hline & ACCOMMODATION & No & YES \\
\hline & TRAVEL COSTS & No & YES \\
\hline & REFRESHMENTS & No & YES \\
\hline
\end{tabular}

By dividing the cost of these two variables - investment and operating - we gained a basic understanding of what these costs are composed. It can not be unambiguously stated which form of education is economically advantageous. It is obvious that the initial investments are clearly higher in e-learning and operating costs are lower. This can be understood as a simple cost model.

The question is how to assess the particular situation. Another part of the paper is devoted to possible methods that can be used and that can help us in making-decision. First, we focus on the savings that result from the introduction of e-learning. Then two models will be presented, which can also be applied.

\subsection{Savings from e-learning}

We can have a look at the issue of introducing e-learning from the perspective of the savings that this form of education brings. 
Graph 1 shows a curve of the savings from e-learning. The curve begins in the traditional teaching. Then there is a downward trend of the curve, i.e. the amount of savings due to implementation of e-learning when it is necessary to spend a relatively high initial investment. The curve even goes below the x-axis, suggesting that at this time we go into negative numbers. We do not create any savings and we have to take some of our own resources, or get some other, external source of funding. The introduction of e-learning is followed by a significant savings. If we introduced "pure e-learning", then the savings were the highest; in the case of the introduction of "blended" e-learning (a certain proportion of contact education) the savings will be slightly lower. In many cases it is of course a better option because the results in education are more optimal, which is certainly an important factor. Subsequently we get to a stable level, where the saving is lower, but vital. This reduction is due to the fact that there is a need in the longer term to update or create new courses, which affects the costs.

The curve clearly shows that the introduction of e-learning is worthy in the cases where use will be long-term. It can be inferred that one of the criteria is the time of use and number of courses. If these courses are few and it will be only a one-time or short-term business, then the initial investments will not return.

Figure 1: Savings from e-learning

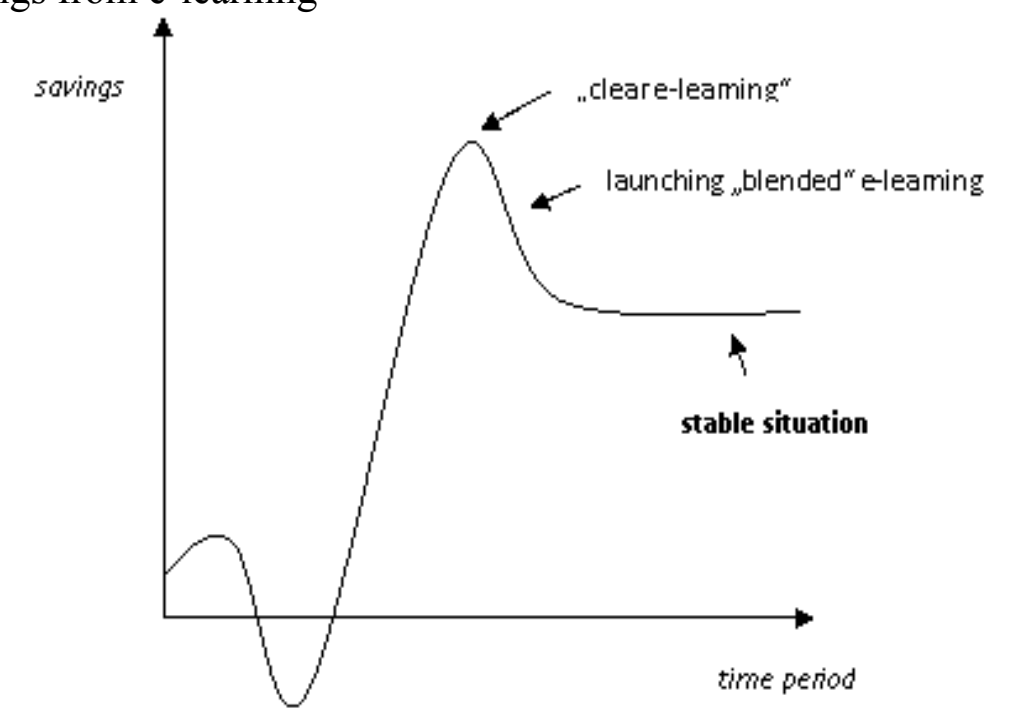

Source: Processed by Balarin (2004)

\subsection{Methods for measuring the economic effectiveness of introducing e-learning}

The following section describes two models that can be applied when deciding on possible investments in e-learning.

\subsubsection{Breaking point}

The graph 2 shows the breaking point. This breaking point shows the intersection of two curves, where the total costs equal performance. In our case, we could use costs as the performance alternative that we incurred for the education of the number of employees in another form (e.g. traditional teaching). The total cost is equal to sum of fixed (in our case initial or investment) costs and variable (in our case intermediate or operating) costs.

In the breaking point the economic profit is zero. In the event that the number of students is about one unit lower, there will be a loss. Otherwise, the project will produce a profit. Breaking point is a turning point when the investment pays off. 
Another criterion therefore is the number of students. If it will only cover a narrow range of students, the inserted investments can not return. This view is also confirmed by the statement from the previous chapter.

Figure 2: Breaking point

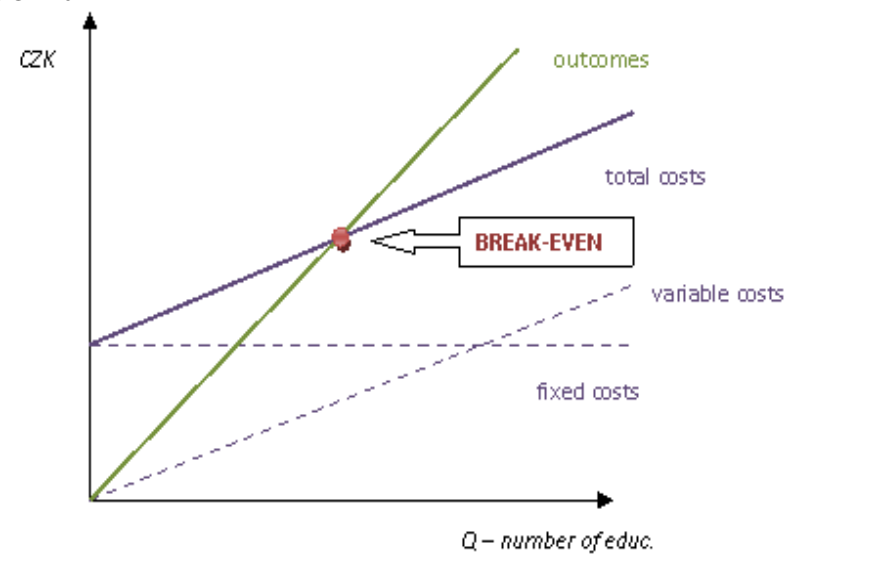

Source: Processed by author

\subsubsection{Phillips/Kirkpatrick's model for measuring the effectiveness of e-learning}

We can meet with a number of studies that demonstrate the benefits of e-learning. These benefits include:

- reducing the cost of tuition,

- ability to cover a significantly higher number of students,

- incorporate more extensive amount of knowledge,

- more efficient management of educational processes,

- increase in the satisfaction of employees and reduction of fluctuation, etc.

At present, however, no company is satisfied merely with statements of these studies. Each investment must be assessed individually and its benefits must be visible and tangible. This is why many companies do not invest in tuition, the benefits of this investment have been difficult to measure. Gradually, however, there is a methodology to measure the effectiveness of e-learning and to apply the calculation of investments returnability in e-learning (Pejsa, 2011).

There is a widely recognized and used method of measuring the effectiveness of educational programs, developed by Donald L. Kirkpatrick in 1959 at the University of Wisconsin. Kirkpatrick's model includes 4 basic levels of evaluation (Philipson, 2009).

Degree 1: Response - How do students respond to the training?

Degree 2: Tuition - How much have they learnt?

Degree 3: Behaviour - How has their behaviour changed?

Degree 4: Results - What was the effect of the training for the organization?

These four degrees were complemented by Jack Phillips' fifth degree:

Degree 5: Return on investment - Did the results of the training outweigh its cost?

This level compares financial benefits with costs incurred.

Return on investment (ROI) measures income compared to the costs needed to achieve them. This can be expressed in a simple mathematical formula:

RoI $=(($ Total income - Cost $) /$ Cost $) * 100$ 
RoI is traditionally used in business accounting, where the individual items can be relatively easily determined. Although this does not apply to e-learning.

RoI can be influenced by two aspects, which is clearly evident from the formula: cost reductions and income increases. Costs can also be quite well established in e-learning, but with income it is more complex. This does not mean that the RoI can not be applied in elearning. On the contrary, RoI techniques may well demonstrate the benefits of e-learning, both in the saving of costs as well as in the increase of revenue (by offering the created courses to other entities).

There are various support programs to increase skills of the population from which these organizations, after meeting certain conditions can draw financial resources aimed at enhancing skills (e.g. workers of entrepreneurs, unemployed people, ...). In the case that these resources are obtained, then the decision from the economic point of view is much easier.

\section{Comparison of the effectiveness of e-learning and traditional teaching - pedagogical experiment results}

Managers are in every organization, whatever its mission may be. Education in management should be a part of the education of every organization. The following section is therefore devoted to comparing the effectiveness of e-learning with traditional teaching in the acquisition of basic management skills. This educational experiment was carried out within the GACR 406/09/0669 project of "Evaluation of the benefits of modern technology in the process of formation and development of competencies of university students ", which, inter alia, was precisely focused on evaluating the effectiveness of e-learning.

\subsection{The objective of the pedagogical experiment}

The research objective was to verify whether appropriate use of e-Learning leads to comparable performance of students in the area of cognitive learning. At first glance it may seem that students and employees are two groups which are difficult to compare. For the purposes of our experiment, i.e. verifying comparability of the effectiveness of e-learning and traditional teaching, the difference is irrelevant. Corporate education also involve various employees (differences in age, education, experience, etc.)

The research objective can be characterized as follows:

1) Learning process in the teaching of the course of The Principles of Management.

2) University students (Faculty of Informatics and Management, University of Hradec Kralove) participating in the course of the Principles of Management.

The research subject is student performance achieved in the experimental group in the cognitive area and its comparison with the achieved performance of students in traditional full-time teaching in the course of the Principles of Management.

The main hypothesis is:

H1 Students in the experimental group will achieve a comparable performance in cognitive learning at the end of the experimental teaching as students taught by traditional full-time teaching. 


\subsection{Methodology and research organization}

The research used the following methods:

- Experiment - the main method,

- Educational tests - verifying the hypothesis,

- interview (to a limited extent),

- observation (to a limited extent),

- statistical methods for processing the results of the research.

A suitable method for comparing the effectiveness of the two different systems of education is a pedagogical experiment.

One of the important condition in the organization of the experiment is that the experimental and control group were as equal as possible. The experimental group is a group of entities in which an experimental change is applied, in our case it is a group of students who use elearning. The control group is a group of entities in which an experimental change is not in progress, in our case those students who use traditional methods of education (full-time teaching).

The experimental method uses a special term to describe the experimental changes - the independent variable. In our educational research the independent variable will be the use of e-learning. The dependent variable in the experiment was the performance of students remembering, understanding and application of new knowledge.

The research used an experimental plan using pre-test and post-test.

When evaluating the effectiveness of learning, didactic texts were used that play an important role here. Entrance test (pre-test) verifies that the initial knowledge of both groups is same. Output test number 1 (post-test) measures, whether experimental change - e-learning influenced knowledge of the students in comparison to traditional learning. Output test number 2 (post-test2) tests the durability of knowledge.

All didactic tests that have been used in the research were determined for the measurement of the results in cognitive learning. When creating tasks in the didactic test, clearly defined objectives and curriculum analysis were used.

Individual tasks were defined based on the taxonomy of educational objectives of Tollinger the first three categories were used:

1. Tasks requiring a commemorative reproduction of knowledge

2. Tasks requiring simple mental operations with knowledge

3. Tasks requiring complex mental skills with knowledge

Number of tasks in the thematic units was set in proportion to the number of hours that are devoted to the interpretation of individual topics.

The pre-test contained eight tasks, the post-test 12 tasks. To determine the reliability of the tests that are not high numbers, but reliability value of the pre-test reached 0.6008 ; the reliability value of the post-test reached 0.672 .

The structure of the post-test is described in the following table (Table 2). 
Table 2: Specification table for the post-test

\begin{tabular}{|c|c|c|c|c|c|}
\hline \multirow{2}{*}{ Tasks } & \multirow{2}{*}{$\begin{array}{c}\text { Number of } \\
\text { tasks }\end{array}$} & \multicolumn{3}{|c|}{$\begin{array}{c}\text { The level of learn } \\
\text { (by Tollinger) }\end{array}$} \\
\cline { 4 - 7 } & & & $\mathbf{1 .}$ & $\mathbf{2 .}$ & $\mathbf{3 .}$ \\
\hline I. & Introduction to Management & 2 & 1 & 1 & \\
\hline I. $\quad$ Decision & 1 & 1 & & \\
\hline II. $\quad$ Management processes & 8 & 3 & 4 & 1 \\
\hline III. $\quad$ Motivation & 1 & & & 1 \\
\hline Total & $\mathbf{1 2}$ & $\mathbf{5}$ & $\mathbf{5}$ & $\mathbf{2}$ \\
\hline
\end{tabular}

Source: Processed by author

\subsection{Study organization}

In the case of "traditional" teaching students had the opportunity to attend lectures and seminars. While attendance at the lectures was not mandatory, attendance at the seminars was recorded and was one of the conditions for gaining credit. The lectures successively present different thematic areas. Verbal presentation of the topics was complemented by PowerPoint presentations. Within the seminars the students were solving various sub-tasks and case studies, and had to prepare a seminar paper (SWOT analysis of the selected product, company, service, etc.) To obtain the credit they also had to pass a mid-term test (at least 7 points out of 14).

For the "experimental" teaching the so-called e-subject of PoM1 was used within the OLIVA virtual learning environment. The basis of the virtual learning environment consists of LMS (Learning Management System), WebCT, in which each e-subject is operated. Students included in the control group did not have access to the e-subject of PoM1 during the semester or prior to the test. For the students of the experimental group a lecture or seminars were not scheduled, instead they had available learning support of e-subject of PoM1. All communication with the teacher took place only in the WebCT environment. Students solve sub-tasks and case studies independently, selected tasks were mandatory, so the students had to prepare and submit them to the lecturer. Course completion was linked to the development and delivery of 8 mandatory sub-tasks and passing the final test.

\subsection{Selection of the research samples}

In current school practice, totally random selection to the experimental research is usually impossible. Available selection was used to select the research subjects, so of course it is inappropriate to generalize the results and say that this applies in every area, with any participants, etc.

The research sample consisted of university students (University of Hradec Kralove, Faculty of Informatics and Management), who participated in the academic years 2009/10 and 2010/2011 in the Course of the Principles of Management.

An experimental and control group was created at random selection. The number of participants in the experiment is shown in the following table (Table 3). In some cases, the number in the post-test is lower than in the pre-test, because not all completed the course. 
Table 3: Numbers of participants in the educational experiment

\begin{tabular}{|l|c|c|c|c|}
\cline { 2 - 5 } \multicolumn{1}{c|}{} & \multicolumn{2}{c|}{ Pre-test } & E & Post-test \\
\cline { 2 - 5 } \multicolumn{1}{c|}{} & E & C & 32 & 34 \\
\hline YEAR 1 & 35 & 37 & 44 & 39 \\
\hline YEAR 2 & 44 & 39 & 76 & 73 \\
\hline TOTAL & 79 & 76 & \multicolumn{2}{c|}{ C } \\
\hline
\end{tabular}

Source: Processed by author

Legenda: $\mathrm{E}$ - experimental group, $\mathrm{C}$ - control group.

\subsection{Analysis of the research results}

Test of the input knowledge - pre-test - was created in order to determine the input level of knowledge before experimental exposure. Because the course of Principles of Management is not attached to another subject, questions related to the substance of the course of the Principles of management were contained in the test. A pre-test was necessary to verify that the input knowledge of students is equivalent; otherwise to carry out the pedagogical experiment would not have point.

At the end of the experiment the participants passed the test of output knowledge - post-test it was created in order to determine the output level of knowledge after experimental exposure. After three months the post-test was repeated to confirm the permanence of the knowledge.

Using the statistical program of NCSS2007, Student t- test (t value) and non-parametric Mann-Whitney test ( $Z$ value - for reasons not entirely clear normal distribution) analysis of variance at the significance level of 0.05 for checking the equivalence of statistical indicators of the samples results in the pre-test and post-test 1 post-test 2 . The results are shown in the following two tables. (Table 4 and 5).

The aim of this test was to verify the hypothesis:

"There is no statistically significant difference between the performances, which in the pretest (initial diagnostic test) and post-test (output diagnostic test) were reached by students included in the control group and students included in the experimental group."

Table 4: Overview of the results - year 1

\begin{tabular}{|l|c|c|c|c|}
\hline & Norm & t - value & Z - value & $\mathbf{H}_{\mathbf{0}}$ \\
\cline { 1 - 2 } Pretest C & $\mathrm{N}$ & $-1,2858$ & $-1,3474$ & Accept \\
\cline { 1 - 2 } Pretest E & $\mathrm{N}$ & & & Accept \\
\cline { 1 - 2 } Posttest C & $\mathrm{N}$ & $-0,2314$ & $-0,1078$ & \\
\cline { 1 - 2 } Posttest E & NR & & & Accept \\
\cline { 1 - 2 } Posttest2 C & NR & \multirow{2}{*}{$-0,2576$} & 0,0974 & \\
\hline
\end{tabular}

Source: Processed by author

Legenda: E - experimental group, C - control group, Norm (test of normality): N (normal distribution), NR (can not reject), $\mathrm{R}$ (rejects) 
Table 5: Overview of the results - year 2

\begin{tabular}{|l|c|c|c|c|}
\hline & Norm & $\mathbf{t}$ - value & $\mathbf{Z}$ - value & $\mathbf{H}_{\mathbf{0}}$ \\
\hline Pretest C & $\mathrm{N}$ & 0,6438 & $-0,4969$ & Accept \\
\cline { 1 - 2 } Pretest E & $\mathrm{N}$ & & & \\
\hline Posttest C & $\mathrm{NR}$ & 0,2722 & $-0,2303$ & Accept \\
\cline { 1 - 2 } Posttest E & $\mathrm{N}$ & & & Accept \\
\cline { 1 - 2 } Posttest2 C & $\mathrm{N}$ & 0,0640 & 0,0328 & \\
\hline
\end{tabular}

Source: Processed by author

Legenda: E - experimental group, C - control group, Norm (test of normality): N (normal distribution), NR (can not reject), R (rejects)

Table critical value of the test criteria is Tcrit $=1,9866$.

All calculated values of the test criteria $\mathrm{T}_{\text {calcul }}$ were lower than the critical value

$$
=T_{\text {vypoč }} \leq T_{\text {krit }}=1,9866 \text { ). }
$$

It is therefore accepted the null hypothesis, i.e. in post-test 1 and post-test 2 there was no statistically significant difference between the performances of students enrolled in the control and experimental group.

The validity of the null hypothesis is confirmed by the non-parametric Mann-Whitney test. Hypothesis "Students in the experimental group will achieve a comparable performance in cognitive learning at the end of the experimental teaching as students taught by traditional full-time teaching" is true.

If in this experiment, with this number of trainees at the University we should consider the economic aspect by calculating the costs, assuming that this form of education is being established, an infrastructure is not set up, creators of the courses are not trained, etc., the opinion would certainly be negative. The main reason was the small number of students and a large initial fixed costs.

\section{Conclusion}

So there are some criteria that should be considered:

I. Economic criteria:

$\checkmark$ number of students - if it is assumed "large" number of students ;

$\checkmark$ the number of repetition rate - if it can be expected that the course will be repeated;

$\checkmark$ ICT facilities in educational institutions and students - if it is at least partially available, so the initial investment is lower,

$\checkmark$ possibility of obtaining subsidies or grants.

II. The suitability of course content for e-learning - learning in this way will be effective.

III. Assumptions on an organization - ICT facilities, staffing.

IV. Assumptions on the students - ICT literacy, access to ICT.

The previous section also provides selected economic aspects, which can help you decide on the introduction of e-learning in education. 
A very important aspect of the introduction of e-learning is the educational system of the organization of course, is its efficiency. Deployment of e-learning is not possible in all cases, it is always necessary to consider very carefully whether it is appropriate to educate the issues with e-learning.

Based on the experiment, we can state that training in basic management skills through elearning is as effective as traditional teaching. This finding is important when deciding on the introduction of this tool in business education. A similar pedagogical experiment was carried out in other areas such as database systems for teaching or professional English. Simonova (2011) confirms these results. Of course all competencies can not be acquired by this way. The area where I don't consider e.g. e-learning as a suitable instrument, basically in the field of management, is education in communication skills. Here in my opinion, the traditional face-to-face teaching is irreplaceable.

Based on this analysis, it certainly can not be unequivocally said that every organization (educational institution, business) should introduce e-learning into the education system of their employees. It is always necessary to consider each organization individually. But there are criteria and tools mentioned that can help you in decision-making.

\section{Acknowledgement}

This paper was supported by project GACR 406/09/0669 "Evaluation of the benefits of modern technologies in the process of formation and development of skills of university students.“

\section{References}

[1] ARMSTRONG, M., 2007. Řizení lidských zdrojů. Praha: Grada Publishing. ISBN: 97880-247-1407-3.

[2] BALARIN, D., Náklady a efektivita e-learningu. [cit. 2012-01-14]. Available from WWW: < http:// www.hr-zive.cz/data/2004-05-05/david_balarin.ppt >.

[3] BARTÁK, J., 2008. Jak vzdělávat dospělé. Praha: Nakladatelství Alfa, s. r. o. ISBN: 978-80-87197-12-7.

[4] ČESKÝ STATISTICKÝ ÚŘAD [cit. 2012-02-14], Available from WWW: < http://www.czso.cz/>.

[5] KOPECKÝ, K., 2006. E-learning (nejen) pro pedagogy. Olomouc: HANEX. ISBN 8085783-50-9.

[6] PEJŠA, J. E-learning - trendy, měření efektivity, ROI, př́padové studie [cit. 2011-0414]. Available from WWW: < http:// www.e-learn.cz/soubory/elearning_trends_ROI.pdf >

[7] PHILIPSON, G. The RoI on e-learning. The australian experience. [cit. 2009-07-19]. Available at: < http://www.philipson.info/files/RoIeLearn.pdf >.

[8] POULOVÁ, P., M. SOKOLOVÁ a I. ŠIMONOVÁ, 2010. Předpoklady zavedení elearningu do vysokoškolského vzdělávání a hodnocení jeho př́nosu v procesu formování a rozvoje kompetenci studentü. AULA, roč. 18/2010, č. 3. Centrum pro studium vysokého školství. ISSN: 1210-6658. 
[9] ŠIMONOVÁ, I., P. POULOVÁ a M. SOKOLOVÁ, 2011. Klíčové kompetence a jejich reflexe $v$ terciárním e-vzdělávání: e-learning $v$ odborné angličtině $v$ komparaci $s$ dalšimi oblastmi manažerského vzdělávání. Hradec Králové: M. Vognar. ISBN: 978-8086771-46-5.

[10] ŠIMONOVÁ, I., P. POULOVÁ, M. ŠABATOVÁ (SOKOLOVÁ), M. BÍLEK a M. MANĚNOVÁ, 2009. On Contribution of Modern Technologies Towards Developing Key Competences. Odborná kniha. Hradec Králové, M. Vognar, Česká republika. ISBN 978-80-86771-38-0. 